

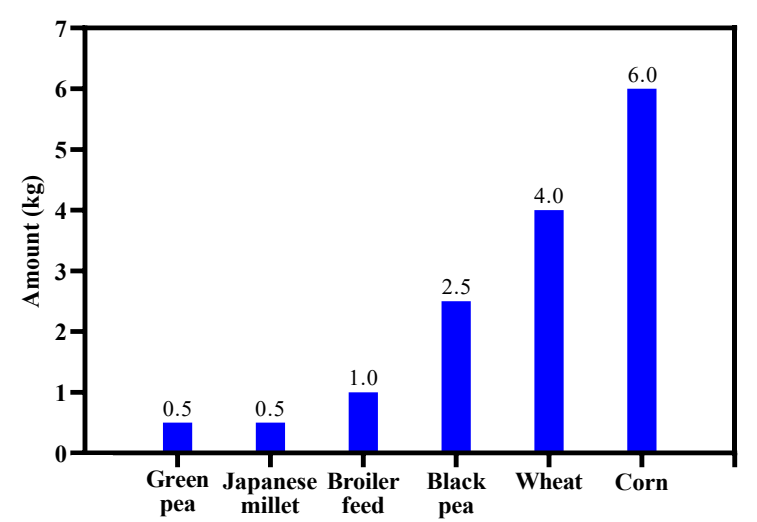

Figure 1. Food stuffs for pigeons.

remedic values like depression, muscle pain, thyroid problems, skin problems, hair loss, nail problems, lower immunity and this meat is enriched with more zinc, phosphorus, iron, sodium, selenium, and copper. Chinese people take pigeons' meat as their medicinal value [27].

\section{FOOD AND NUTRITION}

In the life of pigeons we see their growing, moulting, breeding, laying and hatching stages. Home-made healthy grits are good for the bone formation all the year round. For controlling fungal growth in feed need to dry feed by sunlight. Sometimes, long bristles of paddy can attach to the pigeons' gullet which causes abscess. Supplied water will be clean always. In pre-laying/hatching/ suckling stages- corn $6 \mathrm{~kg}$, wheat $4 \mathrm{~kg}$, black-pea $2.5 \mathrm{~kg}$, Japanese millet $0.5 \mathrm{~kg}$, broiler feed $1 \mathrm{~kg}$, green-pea $0.5 \mathrm{~kg}$ (Figure 1), and mustard $250 \mathrm{~g}$ are suitable [20]. Abd El-Hack et al. [28] mentioned that the feed consumption is about one-tenth of the pigeon's body weight.

\section{PIGEONS' PREDATORS}

A study in Bangladesh suggested that out of 12 predators' mammals were the highest number [29]. In Israel and Bangladesh, golden jackals were seen as scavengers [30]-[32]. Poison bait is used for controlling this golden jackal [33][34]. Sometimes rock-pigeons are killed by predator birds. There are 17 species of raptors are found in Bangladesh consisted of three families- falconidae, accipitridae, and pandionidae [35]. Indeed, falcon does not breed in Bangladesh. A piece of mirror on the long trees beside the farm and irregular flying of tumbler and racing pigeons makes puzzle of the raptors [35]. Snakes can be controlled by using thallium sulfate. To make fear, scarecrow and water spray are useful for protecting such pigeons [29]. Monitor-lizards may come near the loft for carcasses. For protecting pigeons, farmers should know the breeding season of crows. Pit Bull, Fox Terrier, and Airedale Terrier dogs are good for patrolling the loft [36]. Treepie (Dendrocitta spp.) consumes 64\% insect in the crop field and only attacks $0.1 \%$ to Columba livia nestling [37]. One inch mesh size is sufficient for controlling sparrows within the loft. White feathered pigeons are always caught by the predators.

\section{DISEASES OF PIGEONS AND CAGE SANITARY}

Out of 20 diseases of pigeons in Bangladesh $30 \%$ were for bacterium, $20 \%$ viruses, $15 \%$ rearing related, protozoan and vitamin deficiency $10 \%, 5 \%$ for fungal, and Mycoplasma and food related 5\% [38] (Figure 2). In the country most pigeon keepers are not conscious about the diseases of their pigeons. Some mycotic, bacterial, protozoal, chlamydial, rickettsial, and parasitic diseases are considered as zoonotic diseases and their numbers are approximately thirty [39]. Pigeons are occasionally treated as zoonotic harbour. Pigeons waste carries Aspergillus fungus and $2 \%$ Salmonella bacterium. Dirty water mainly after pigeons' bath is the great source of fluke and lots of mites. Runt, King, and Strasser are higher intensity of parasites and other study showed that older pigeons can be affected by Trichomonas gallinae. Coccidiosis/Blood dysentery is second common problem of all farms. Disinfection by using savlon,

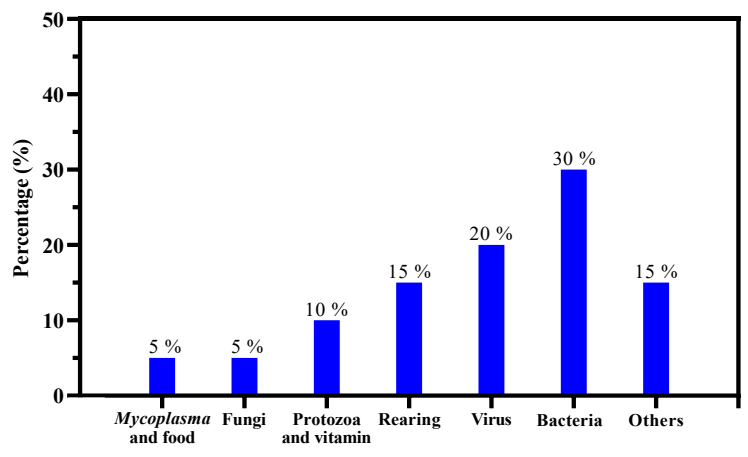

Figure 2. Percentages of disease incidents. 
Table 1. Important features of pigeons with references.

\begin{tabular}{llc}
\hline \multicolumn{1}{c}{ Features } & \multicolumn{1}{c}{ Examples } & References \\
\hline Amusement & Pigeons flying was prehistoric hobby of human being & {$[41]$} \\
Characteristics & Good ranked pigeons are must for better production & {$[7][16][21][29]$} \\
Moulting & $\begin{array}{l}\text { Some rules should maintain during moulting especially } \\
\text { food }\end{array}$ & {$[20]$} \\
Feed & Different stages of pigeons need different type of mixed & {$[20]$} \\
Pigeon predators & food & {$[35]$} \\
Diseases & Preventive and biological are the effective method & {$[38]$} \\
Genetics & Cleaning is the best option & {$[42]$} \\
\hline
\end{tabular}

dettol, potash, and bleaching powder is good at all. Excessive number of birds in a narrow space and poor ventilation causes the ammonia toxicosis that enhances ocular discharge. Newly fledged pigeons' showed the highest mortality and time between fledging and settlement in a feeding flock is crucial [40].

\section{CONCLUSIONS}

Bangladesh is an excellent harbour for many fancy pigeons. All birds have true markings but need to ensure those characteristics by the keepers by keen observation. We can establish a pigeon farm only for human meat consumption after fulfilling our hobby. In this regard, king pigeon, strasser, and maltese breeds can be good perspective Bangladesh. Without nutritious food, it is quite impossible to get sufficient meat from the squabs and nice pairs for the fulfillment of our hobby. Different stages of pigeons need different food ratios with sufficient home-made grits. We should increase our knowledge for understanding purebreds either they are fancy or table breed. In addition, we need to overcome major limitations such as cleanliness and balanced diet for achieving positive impact in our economy.

\section{AUTHOR INFORMATION}

\section{Corresponding Author}

M. Ashraful Kabir - Department of Biology, Cantonment Public College, Saidpur Cantonment - 5311 (Bangladesh); (D) orcid.org/0000-0001-7093-2741
Email: ashraful.mission@gmail.com

\section{CONFLICT OF INTEREST}

The authors declare that there is no conflict of interest.

\section{REFERENCES}

[1] M. A. Kabir, T. J. Hawkeswood, and D. Makhan. (2020). "Pigeon flying in the world: a brief review". Calodema. $809: 1-4$.

[2] J. Bruxaux, M. Gabrielli, H. Ashari, R. PrŷsJones, L. Joseph, B. Milá, G. Besnard, and C. Thébaud. (2018). "Recovering the evolutionary history of crowned pigeons (Columbidae: Goura): Implications for the biogeography and conservation of New Guinean lowland birds". Molecular Phylogenetics and Evolution. 120 : 248-258. 10.1016/j.ympev.2017.11.022.

[3] A. Gagliardo, S. Colombo, E. Pollonara, G. Casini, M. G. Rossino, M. Wikelski, and V. P. Bingman. (2021). "GPS-profiling of retrograde navigational impairments associated with hippocampal lesion in homing pigeons". Behavioural Brain Research. 412 : 113408. 10.1016/ j.bbr.2021.113408.

[4] M. Ohkita and M. Jitsumori. (2012). "Pigeons show efficient visual search by category: Effects of typicality and practice". Vision Research. 72 : 63-73. 10.1016/ j.visres.2012.09.013.

[5] L. C. Zulu, E. A. Adams, R. Chikowo, and S. Snapp. (2018). "The role of community- 
based livestock management institutions in the adoption and scaling up of pigeon peas in Malawi”. Food Policy. 79 : 141-155. 10.1016/j.foodpol.2018.06.007.

[6] H. M. Santos, C. Y. Tsai, G. E. M. Catulin, K. C. G. Trangia, L. L. Tayo, H. J. Liu, and K. P. Chuang. (2020). "Common bacterial, viral, and parasitic diseases in pigeons (Columba livia): A review of diagnostic and treatment strategies". Veterinary Microbiology. 247 : $108779 . \quad \underline{10.1016 /}$ j.vetmic.2020.108779.

[7] M. A. Kabir. (2020). "King Pigeons Can be the King of Meat in Bangladesh". Journal of Agricultural. $7: 6-9$.

[8] Y. A. Mulyani, F. N. Tirtaningtyas, N. K. Hadi, L. K. Dewi, and A. Kaban. (2017). "Molt in Birds Inhabiting a HumanDominated Habitat". HAYATI Journal of Biosciences. 24 (4): 195-200. 10.1016/ j.hjb.2017.11.004.

[9] H. G. Wallraff. (2010). In: "Encyclopedia of Animal Behavior". Elsevier.

[10] I. Schiffner, J. Baumeister, and R. Wiltschko. (2011). "Mathematical analysis of the navigational process in homing pigeons". Journal of Theoretical Biology. 291 : 42-46. 10.1016/j.jtbi.2011.09.009.

[11] H. G. Wallraff. (2019). In: "Encyclopedia of Animal Behavior". Elsevier.

[12] S. A. Stringham, E. E. Mulroy, J. Xing, D. Record, M. W. Guernsey, J. T. Aldenhoven, E. J. Osborne, and M. D. Shapiro. (2012). "Divergence, Convergence, and the Ancestry of Feral Populations in the Domestic Rock Pigeon". Current Biology. 22 (4): 302-308. 10.1016/j.cub.2011.12.045.

[13] S. Haunshi, R. Basumatary, P. S. Girish, S. Doley, R. K. Bardoloi, and A. Kumar. (2009). "Identification of chicken, duck, pigeon and pig meat by species-specific markers of mitochondrial origin". Meat Science. 83 (3): 454-459. $10.1016 /$ j.meatsci.2009.06.026.

[14] O. Lapiedra, D. Sol, S. Carranza, and J. M. Beaulieu. (2013). "Behavioural changes and the adaptive diversification of pigeons and doves". Proceedings of the Royal Society B: Biological Sciences. 280 (1755): 20122893. 10.1098/rspb.2012.2893.

[15] M. A. Kabir. (2015). "Tumbler Pigeons are very ancient and most favourite in Bangladesh". International Journal of Research in Pharmacy and Biosciences. 2 (1): 10-13.

[16] M. A. Kabir. (2013). "Productivity of crossed indigenous Pigeon in semi intensive system". Journal of Agricultura. 2 (1): 1-4.

[17] M. A. Kabir. (2014). "Grading system of ten common fancy pigeons of Bangladesh". Integrated Journal of British. 1 (1): 19-26.

[18] J. Wang, J. Li, F. Liu, Y. Cheng, and J. Su. (2020). "Characterization of Salmonella enterica Isolates from Diseased Poultry in Northern China between 2014 and 2018". Pathogens. 9 (2): $95 . \quad \underline{10.3390 /}$ pathogens 9020095 .

[19] E. Kaczorek-Łukowska, P. Sowińska, A. Franaszek, D. Dziewulska, J. Małaczewska, and T. Stenzel. (2020). "Can domestic pigeon be a potential carrier of zoonotic Salmonella?". Transboundary and Emerging Diseases. 10.1111/tbed.13891.

[20] M. A. Kabir. (2018). "Pigeons' Feed at their Various Stages". International Journal of Research Studies in Zoology. 4 (2). 10.20431/2454-941x.0402005.

[21] M. A. Kabir. (2014). "Major pigeon markets in Dhaka, Bangladesh". Extensive Journal of Applied Sciences. 2 (1): 6-8.

[22] F. Balci, S. Ardiçli, F. Alpay, D. Dinçel, B. Soyudal, and M. Er. (2018). "The determination of some morphological characteristics of Bursa Oynarı pigeon breed". Ankara Universitesi Veteriner Fakultesi Dergisi. 65 (4): 349-355. 10.1501/ Vetfak 0000002867.

[23] P. Mazengenya, A. Bhagwandin, P. Nkomozepi, P. Manger, and A. Ihunwo. (2017). "Putative adult neurogenesis in two domestic pigeon breeds (Columba livia domestica): racing homer versus utility carneau pigeons". Neural Regeneration Research. 12 (7): 1086. 10.4103/16735374.211187.

[24] A. Gáspárdy. (2017). “Connection among Body Measurements and Flying Speed of Racing Pigeon". International Journal of 
Agricultural Science and Food Technology. 009-018. 10.17352/2455-815X.000016.

[25] L. M. Tuttle-Adams. (2020). In: "HandRearing Birds". Wiley.

[26] H. G. de Silva, M. G. Pérez Villafaña, J. Cruz-Nieto, and M. Á. Cruz-Nieto. (2020). "Are some of the birds endemic to the Tres Marías Islands (Mexico) species?”. Bulletin of the British Ornithologists' Club. 140 (1):

7. 10.25226/bboc.v140i1.2020.a3.

[27] C. Y. Lien, C. W. Lu, C. H. Hsu, T. Y. Chuang, L. Y. Su, W. J. Wu, Y. S. Jheng, M. C. Lee, and C. H. Wu. (2020). "Chinese Veterinary Medicine B307 Promotes Cardiac Performance and Skeletal Muscle Contraction via Enhancing Intracellular Calcium Levels and Neural Electrical Activity in Animal and Cell Models". Evidence-Based Complementary and Alternative Medicine. $\mathbf{2 0 2 0}$ : 1-10. 10.1155/2020/9064824.

[28] M. E. Abd El-Hack, A. A. Swelum, M. A. Abdel-Latif, D. Más Toro, and M. Arif. (2018). "Pigeon Pea ( Cajanus cajan ) as an alternative protein source in broiler feed". World's Poultry Science Journal. 74 (3): 541 -548. 10.1017/S0043933918000296.

[29] M. A. Kabir. (2018). "Common wildlife pests in pigeon keeping of Bangladesh". Journal of Dairy, Veterinary \& Animal $\begin{array}{llll}\text { Research. } & 7 & \text { (5). } \quad \underline{10.15406 /}\end{array}$ jdvar.2018.07.00216.

[30] J. Lanszki, M. W. Hayward, and N. Nagyapáti. (2018). "Feeding responses of the golden jackal after reduction of anthropogenic food subsidies" PLoS One. 13 (12): $\quad \mathrm{e} 0208727 . \quad \underline{10.1371 /}$ journal.pone. 0208727.

[31] V. Arkumarev, D. Dobrev, A. Stamenov, N. Terziev, A. Delchev, and S. Stoychev. (2020). "Using GPS and accelerometry data to study the diet of a top avian scavenger". Bird Study. $67 \quad$ (3): $300-310$. 10.1080/00063657.2020.1864285.

[32] A. F. N. Abd Rabou, K. E. Elkahlout, F. A. Almabhouh, W. F. Mohamed, N. A. Khalaf, M. A. Al-Sadek, R. N. Alfarra, L. T. AlMoqayed, A. A. Shafei, N. A. Fayyad, B. S. Adeem, A. W. Dardona, A. S. Awad, M. R.
Al-Agha, and M. A. Abd Rabou. (2021). "Occurrence and Some Ecological Aspects of the Golden Jackal (Canis aureus Linnaeus, 1758) in the Gaza Strip, Palestine”. Open Journal of Ecology. 11 (2): 105-125. 10.4236/oje.2021.112010.

[33] N. Spassov and I. Acosta-Pankov. (2019). "Dispersal history of the golden jackal (Canis aureus moreoticus Geoffroy, 1835) in Europe and possible causes of its recent population explosion". Biodiversity Data Journal. 7. 10.3897/BDJ.7.e34825.

[34] K. Koeppel, B. Kuhn, and P. Thompson. (2020). "Oral bait preferences for rabies vaccination in free-ranging black-backed jackal (Canis mesomelas) and non-target species in a multi-site field study in a periurban protected area in South Africa". Preventive Veterinary Medicine. 175 : 104867. 10.1016/j.prevetmed.2019.104867.

[35] M. A. Kabir. (2012). "Abundance and distribution of the raptors in Bangladesh". International Journal of Livestock Production. 3 (5). 10.5897/IJLP11.058.

[36] T. Stenzel, G. Woźniakowski, D. Pestka, D. Choszcz, B. Tykałowski, M. Śmiałek, and A. Koncicki. (2017). "Application of pigeon circovirus recombinant capsid protein for detecting anti-PiCV antibodies in the sera of asymptomatic domestic pigeons and the potential use of a combination of serological and molecular tests for controlling circovirus infections in pigeon breeding flocks". Poultry Science. 96 (2): 303-308. 10.3382/ ps/pew266.

[37] P. P. M. Basheer and S. K. Thomas. (2012). "Indian Treepie Dendrocitta vagabunda parvula (Latham, 1790) (Passeriformes: Corvidae) as a natural enemy of the pests of coconut and areca palm plantations". Journal of Biopesticides. 5 : 205-208.

[38] M. A. Kabir. (2014). "Symptomatic treatments of some common diseases of fancy Pigeons in Bangladesh". Acme Journal of Animal Science, Livestock production and Animal Breeding. 1 (1): 1-4.

[39] S. A. Burt, R. E. Röring, and M. Heijne. (2018). "Chlamydia psittaci and C. avium in feral pigeon ( Columba livia domestica ) 
droppings in two cities in the Netherlands".

Veterinary Quarterly. 38 (1): 63-66. 10.1080/01652176.2018.1482028.

[40] S. A. Naz, M. Yaseen, N. Jabeen, and M. Shafique. (2017). "Isolation of potentially pathogenic fungi from selected pigeons' feeding sites in Karachi: A new dimension to health hazard". Journal of the Pakistan Medical Association. 67 (6): 901-906.

[41] M. A. Kavesh. (2018). "From the Passions of Kings to the Pastimes of the People: Pigeon Flying, Cockfighting, and Dogfighting in South Asia". Pakistan Journal of Historical Studies. 3 (1): 61. 10.2979/pjhs.3.1.04.

[42] F. Zavinon, H. Adoukonou-Sagbadja, J. Keilwagen, H. Lehnert, F. Ordon, and D. Perovic. (2020). "Genetic diversity and population structure in Beninese pigeon pea [Cajanus cajan (L.) Huth] landraces collection revealed by SSR and genome wide SNP markers". Genetic Resources and Crop Evolution. 67 (1): 191-208. 10.1007/s10722019-00864-9. 